FOLIA POMERANAE UNIVERSITATIS TECHNOLOGIAE STETINENSIS

Folia Pomer. Univ. Technol. Stetin., Oeconomica 2017, 335(87)2, 181-192

Bożena NADOLNA

\title{
EWALUACJA STUDIÓW PODYPLOMOWYCH Z ZAKRESU RACHUNKOWOŚCI. WYNIKI BADAŃ ANKIETOWYCH
}

\section{THE EVALUATION OF THE POSTGRADUATE ACCOUNTING STUDIES. THE RESULTS OF SURVEYS}

Zakład Ekonomii i Rachunkowości, Zachodniopomorski Uniwersytet Technologiczny w Szczecinie, ul. Żołnierska 47, 71-210 Szczecin, e-mail: bozena.nadolna@zut.edu.pl

\begin{abstract}
Summary. The aim of this article is to evaluate the program of postgraduate studies in the field of accounting at the Faculty of Economics of the West Pomeranian University of Technology in Szczecin. The article presents the importance and scope of evaluation of postgraduate studies programs. Then the types of evaluation were discussed. The final part of the article presents the results of the survey studies of the program of study and its implementation at postgraduate studies in accounting. The survey was filled by respondents of five consecutive postgraduate studies. The results of the study indicate that the program and the implementation of the study in a large part were positively evaluated. The proposition presented by the respondents were taken into account when was deployed a new study program, which has been in place since 2016.
\end{abstract}

Słowa kluczowe: studia podyplomowe, ewaluacja programu kształcenia, studium przypadku. Key words: postgraduate studies, program of study, evaluation, case study.

\section{WSTĘP}

Proces nauczania we wszystkich formach kształcenia na uczelni powinien podlegać ewaluacji, której istotą jest ocena programu kształcenia i sposobu jego realizacji na podstawie analizy dokumentacji, jak również uzyskanej informacji zwrotnej od osób bezpośrednio się uczących. Systematyczne zbieranie i ocena informacji o warunkach, przebiegu i wynikach dydaktycznych ma za zadanie zwiększać efekty nauczania.

Jedną z form kształcenia na uczelni są studia podyplomowe. Proces dydaktyczny na tych studiach wymaga szczególnego podejścia do działań ewaluacyjnych uwzględniających ich uwarunkowania społeczne, prawne i zawodowe; jedną z technik ewaluacji jest ankietyzacja.

Celem artykułu jest ocena programu studiów podyplomowych z zakresu rachunkowości na Wydziale Ekonomicznym Zachodniopomorskiego Uniwersytetu Technologicznego w Szczecinie (ZUT).

W artykule przedstawiono znaczenie i zakres ewaluacji programów kształcenia na studiach podyplomowych. Następnie omówiono rodzaje ewaluacji. W końcowej części artykułu zaprezentowano wyniki badań ankietowych oceniające program studiów i jego realizację na studiach podyplomowych z zakresu rachunkowości prowadzonych na Wydziale Ekonomicznym ZUT w Szczecinie. Ankieta została wypełniona przez słuchaczy 5 kolejnych edycji studiów podyplomowych. 


\section{ISTOTA I RODZAJE EWALUACJI PROGRAMÓW NAUCZANIA NA STUDIACH PODYPLOMOWYCH}

Słownik języka polskiego (1988) definiuje ewaluację jako „ustalanie wartości i ceny czegoś, ocenianie, oszacowanie". March i Simon (1964) uznają, że ewaluacja to systematyczny proces obejmujący zbieranie informacji oraz zdawanie relacji (w postaci raportu) z tego, jak się rzeczy mają, z intencją dostarczenia danych ułatwiających podejmowanie decyzji. Z kolei Guilbert (1990) twierdzi, że jest to „[....] proces diagnostyczno-oceniający, zawierający w sobie elementy pomiaru, osądu i decyzji" (s. 145). Szczególne znaczenie działania ewaluacyjne mają w pedagogice. W dziedzinie tej interpretuje się to pojęcie jako „[...] zaplanowany, systematyczny proces o charakterze poznawczym i wartościującym, obejmujący projektowanie czynności badawczych, zbieranie, analizę i ocenę danych dotyczących jakiegoś działania (np. programu), a następnie prezentowanie ich zainteresowanym odbiorcom" (Definicje ewaluacji, http://www.pcdzn.edu.pl/publikacje/Granty/ewaluacja.pdf) lub jako proces w nauczaniu polegający na systematycznym badaniu wartości albo cech konkretnego programu, planu, działania bądź obiektu (programu nauczania) z punktu widzenia przyjętych kryteriów w celu jego usprawnienia, rozwoju lub lepszego zrozumienia. W praktyce wyróżnia się różne rodzaje ewaluacji, co przedstawia tab. 1.

Tabela 1. Rodzaje ewaluacji kształcenia

\begin{tabular}{|c|c|c|}
\hline Kryterium ewaluacji & Rodzaj ewaluacji & Charakterystyka danego rodzaju ewaluacji \\
\hline \multirow{2}{*}{ Termin } & wstępna & $\begin{array}{l}\text { przeprowadzana przed właściwą oceną; służy często roz- } \\
\text { poznaniu obszarów dalszej ewaluacji }\end{array}$ \\
\hline & końcowa & $\begin{array}{l}\text { ewaluacja właściwa, która kończy się wynikami końcowymi } \\
\text { oceny }\end{array}$ \\
\hline \multirow[t]{2}{*}{ Podmiot } & własna & $\begin{array}{l}\text { decyzję o ewaluacji i obszarach nią objętych, kryteriach i spo- } \\
\text { sobie jej przeprowadzenia podejmuje osoba, instytucja ewalu- } \\
\text { owana }\end{array}$ \\
\hline & obca & $\begin{array}{l}\text { decyzję o ewaluacji i obszarach nią objętych, kryteriach i spo- } \\
\text { sobie jej przeprowadzenia podejmuje jednostka zewnętrzna }\end{array}$ \\
\hline \multirow[b]{2}{*}{ Przedmiot } & proces & ewaluacji jest poddany ciąg działań i procedur \\
\hline & produkt & $\begin{array}{l}\text { ewaluacji sa poddane efekty działań zwane wynikami, rezul- } \\
\text { tatami procesu, powstałymi „produktami” }\end{array}$ \\
\hline \multirow{2}{*}{ Zakres } & fokusowa, wyrywkowa & $\begin{array}{l}\text { bada wybrane obszary, często jest realizowana na etapie } \\
\text { wstępnym oceny }\end{array}$ \\
\hline & szerokozakresowa & $\begin{array}{l}\text { bada cały zakres kształcenia, na przykład program kształcę- } \\
\text { nia na kierunku studiów }\end{array}$ \\
\hline \multirow{3}{*}{ Rodzaj } & $\begin{array}{l}\text { profesjonalny } \\
\text { monitoring }\end{array}$ & $\begin{array}{l}\text { zbiera informacje na temat odbioru przez uczestników po- } \\
\text { szczególnych aspektów warsztatu, kursu czy działań nauczy- } \\
\text { cielskich (trenerskich, liderskich itp.) }\end{array}$ \\
\hline & profesjonalny przegląd & $\begin{array}{l}\text { dostarcza informacji na temat wpływu kursu, warsztatu czy } \\
\text { działań na jego uczestników; zadawane pytania dotyczą wpły- } \\
\text { wu procesu nauczania na uczestników, jego użyteczności, } \\
\text { realizacji zakładanych celów oraz pojawiania się niezaplano- } \\
\text { wanych efektów uczenia się }\end{array}$ \\
\hline & ewaluacja zbiorcza & $\begin{array}{l}\text { wiąże się z krytycznym całościowym spojrzeniem na pod- } \\
\text { stawowe założenia i przyjętą praktykę oceny; uczestnicy } \\
\text { i organizatorzy mogą wyrażać własne opinie, dzięki czemu } \\
\text { nawzajem się uczą, a tym samym mają wpływ na całość } \\
\text { przedsięwzięcia }\end{array}$ \\
\hline \multirow[t]{2}{*}{ Metoda } & jednometodyczna & $\begin{array}{l}\text { wykorzystująca tylko jedną metodę badawczą, na przykład } \\
\text { badania ankietowe. }\end{array}$ \\
\hline & wielometodyczna & wykorzystująca triangulację wewnątrz- lub zewnątrzmetodyczną \\
\hline
\end{tabular}

Źródło: opracowano na podstawie: Ewaluacja w pracy (http://erasmusplus.org.pl/wp-content/uploads/2014/02/ /pajp_iv_ewaluacja_w_pracy.pdf). 
W szkolnictwie wyższym przez pojęcie ewaluacji rozumie się narzędzie formułowania opinii na podstawie wskaźników (jakościowych lub ilościowych) uznanych za ważne i wiarygodne do oceny procesu działalności statutowej uczelni. Mizikaci (2006) uważa, że za pomocą tych wskaźników porównuje się faktyczne efekty programu kształcenia z oczekiwanymi. Zdaniem Stachowiak-Kudły (2016) jest to droga do urzeczywistnienia realizacji w szkołach wyższych zarządzania publicznego bazującego na dowodach (evidence based policy). Tym samym celem ewaluacji na uczelni jest zwiększenia skuteczności, użyteczności, efektywności działań edukacyjnych i naukowych.

Z powyższego wynika, iż ewaluacja w szkole wyższej może dotyczyć zarówno obszaru kształcenia, jak i nauki. W ramach działań edukacyjnych głównym przedmiotem ewaluacji mogą być programy nauczania realizowane w poszczególnych formach kształcenia; jedną $z$ takich form są studia podyplomowe.

\section{CHARAKTERYSTYKA PROGRAMU KSZTAKCENIA NA STUDIACH PODYPLOMOWYCH Z ZAKRESU RACHUNKOWOŚCI NA WYDZIALE EKONOMICZNYM ZACHODNIOPOMORSKIEGO UNIWERSYTETU TECHNOLOGICZNEGO W SZCZECINIE}

W nowym systemie kształcenia na uczelniach kluczowym terminem jest program kształcenia. Zgodnie z definicją, sformułowaną w art. 2 ust. 1 pkt 14b Ustawy z dnia 27 lipca 2005 r. o szkolnictwie wyższym, program kształcenia to opis określonych przez uczelnię spójnych efektów kształcenia, zgodny z krajowymi ramami kwalifikacji dla szkolnictwa wyższego ${ }^{1}$, oraz opis procesu kształcenia prowadzącego do osiągnięcia tych efektów, wraz z przypisanymi do poszczególnych modułów tego procesu punktami ECTS. ${ }^{2}$ Przy czym nie należy utożsamiać pojęcia „program kształcenia” z terminem „program studiów”. Wynika to z zapisów Rozporządzenia Ministra Nauki i Szkolnictwa Wyższego z dnia 26 września 2016 r. w sprawie warunków prowadzenia studiów w sprawie warunków prowadzenia studiów (DzU z 2016 r., poz. 1596), w którym określa się, że program kształcenia dla danego kierunku i poziomu kształcenia oraz dla danego profilu lub profili kształcenia na tym kierunku obejmuje opis zakładanych efektów kształcenia ${ }^{3}$ i program studiów, stanowiący opis procesu kształcenia prowadzącego do uzyskania tych efektów. Oznacza to, że program studiów jest jednym z elementów programu kształcenia i stanowi formalną wykładnię jego treści. Zazwyczaj składają się na niego odpowiednio uporządkowane zbiory tematów z wybranych dziedzin wiedzy, które są realizowane w procesie nauczania. Ponadto w programie tym ustala się harmonogram przyswajania wiedzy i nabywania kolejnych kwalifikacji.

\footnotetext{
${ }^{1}$ Krajowe ramy kwalifikacji dla szkolnictwa wyższego - ogólne charakterystyki efektów uczenia się dla kwalifikacji na poziomach 6 i 7 polskiej ramy kwalifikacji - zob. Ustawa z dnia 22 grudnia 2015 r. o Zintegrowanym Systemie Kwalifikacji. DzU z 2016 r., poz. 64, 1010.

2 Punkty ECTS - punkty zdefiniowane w europejskim systemie akumulacji i transferu punktów zaliczeniowych jako miara średniego nakładu pracy osoby uczącej się, niezbędnego do uzyskania zakładanych efektów kształcenia zob. art. 2.1, pkt 18d Ustawy z dnia 27 lipca 2005 r. Prawo o szkolnictwie wyższym. DzU z 2016 r., poz. 1842.

${ }^{3}$ Efekty kształcenia - zasób wiedzy, umiejętności i kompetencji społecznych uzyskiwanych w procesie kształcenia w systemie studiów oraz studiów trzeciego stopnia.
} 
Jak już wspomniano, jedną z form kształcenia na uczelni są studia podyplomowe, na które są przyjmowani kandydaci posiadający kwalifikacje co najmniej pierwszego stopnia. Warunkiem ich ukończenia jest uzyskanie kwalifikacji podyplomowych potwierdzających zakładane efekty kształcenia, poświadczone dyplomem, świadectwem, certyfikatem lub innym dokumentem wydanym przez uprawnioną uczelnię; dotyczy to również studiów podyplomowych z zakresu rachunkowości (Nadolna 2013).

Istotnym elementem programu takich studiów jest odpowiedni podział jego treści na części wykładowe, audytoryjne i laboratoryjne. Szczególną rolę w procesie nauczania rachunkowości odgrywają zajęcia laboratoryjne i audytoryjne, gdyż mają one za zadanie kształtować umiejętności i nawyki niezbędne do prowadzenia ksiąg rachunkowych, ich wykorzystywania oraz interpretacji. Tworzenie takiego programu, a następnie jego realizacja powinna być poddawana ewaluacji. Ocenie takiej został poddany program studiów podyplomowych z zakresu rachunkowości na Wydziale Ekonomicznym ZUT w Szczecinie. Program ten w 2016 roku został w niewielkim stopniu zmodyfikowany. Wyłączono z niego takie przedmioty, jak: rachunkowość zarządcza, podstawy prawa gospodarczego, prawo finansowe i rachunkowość w szczególnych sytuacjach. Treści tego ostatniego przedmiotu przeniesiono do zakresu tematycznego rachunkowości finansowej II. Zrezygnowano również z obowiązującego pisania pracy dyplomowej, co spowodowało wyłączenie z planu studiów seminarium dyplomowego. Treści tematyczne zmienionego programu wraz z efektami kształcenia zostały przedstawione w tab. 2.

Zakładane efekty kształcenia wskazują sylwetkę absolwenta studiów podyplomowych „Rachunkowość” na Wydziale Ekonomicznym ZUT w Szczecinie. Osoba kończąca te studia będzie posiadać wiedzę i umiejętności z zakresu prawa bilansowego i podatkowego. W szczególności będzie znała zasady organizacji i ujmowania zdarzeń gospodarczych w księgach rachunkowych. Będzie potrafiła prezentować te zdarzenia w sprawozdaniach finansowych oraz interpretować informacje w nich zawarte. Ponadto będzie posiadała umiejętność kalkulowania i rozliczania kosztów wytworzenia produktów i usług oraz będzie potrafiła obsługiwać wybrany system finansowo-księgowy. Dodatkowo pozna i będzie wykorzystywać $\mathrm{w}$ praktyce problematykę prawa podatkowego wynikającą $\mathrm{z}$ ordynacji podatkowej oraz ustaw o podatkach dochodowych i VAT.

Studia te mają na celu przygotowanie absolwentów do pracy na stanowiskach księgowych w biurach rachunkowych, centrach usług wspólnych, małych i średnich przedsiębiorstwach, jak również w innych jednostkach, na przykład sektora publicznego. Umożliwiają one również właścicielom i zarządzającym przedsiębiorstwami zrozumienie podstawowych zasad rachunkowości oraz wpływu ich decyzji na wyniki prezentowane w poszczególnych pozycjach rocznego sprawozdania finansowego. Nabyte kompetencje społeczne pozwolą absolwentom studiów zrozumieć znaczenie przestrzegania etyki zawodu księgowego. 
Tabela 2. Treści programowe oraz zakładane efekty kształcenia na studiach podyplomowych „Rachunkowość” na Wydziale Ekonomicznym ZUT w Szczecinie

\begin{tabular}{|c|c|c|c|c|}
\hline \multirow{2}{*}{$\begin{array}{l}\text { Nazwa } \\
\text { przedmiotu }\end{array}$} & \multirow{2}{*}{$\begin{array}{l}\text { Liczba } \\
\text { godzin }\end{array}$} & \multicolumn{3}{|c|}{ Zakładane efekty kształcenia } \\
\hline & & wiedza & umiejętności & $\begin{array}{c}\text { inne kompetencje } \\
\text { społeczne }\end{array}$ \\
\hline \multicolumn{5}{|c|}{ I semestr } \\
\hline $\begin{array}{l}\text { Podstawy } \\
\text { rachunkowości } \\
\text { (teoria } \\
\text { rachunkowości) }\end{array}$ & 20 & $\begin{array}{l}\text { słuchacz zna istotę ra- } \\
\text { chunkowości, jej funkcje } \\
\text { zasady i zakres oraz re- } \\
\text { gulacje prawne, jak rów- } \\
\text { nież sposób ujęcia ope- } \\
\text { racji w księgach rachun- } \\
\text { kowych i sprawozdaniach } \\
\text { finansowych }\end{array}$ & $\begin{array}{l}\text { słuchacz potrafi ując ope- } \\
\text { racje gospodarcze przed- } \\
\text { siębiorstwa w księgach } \\
\text { rachunkowych, a następ- } \\
\text { nie przedstawić je i zin- } \\
\text { terpretować w bilansie } \\
\text { i rachunku zysków i strat }\end{array}$ & $\begin{array}{l}\text { słuchacz posiada zdol- } \\
\text { ność do samodzielnego } \\
\text { i grupowego rozwiązy- } \\
\text { wania problemów ewiden- } \\
\text { cyjnych w rachunkowości } \\
\text { prezentowanych na za- } \\
\text { jęciach }\end{array}$ \\
\hline $\begin{array}{l}\text { Organizacja } \\
\text { rachunkowości }\end{array}$ & 10 & $\begin{array}{l}\text { słuchacz zna istotę, za- } \\
\text { kres i narzędzia organi- } \\
\text { zacji rachunkowości, w tym } \\
\text { zasady organizacji doku- } \\
\text { mentacji i ewidencji księ- } \\
\text { gowej, inwentaryzacji, prac } \\
\text { sprawozdawczych; poznał } \\
\text { organizację działu rachun- } \\
\text { kowości oraz zasady etyki } \\
\text { zawodu księgowego }\end{array}$ & $\begin{array}{l}\text { słuchacz potrafi zastoso- } \\
\text { wać narzędzia organiza- } \\
\text { cji rachunkowości do stwo- } \\
\text { rzenia zgodnego z pra- } \\
\text { wem bilansowym obiegu } \\
\text { dokumentów, procesu ewi- } \\
\text { dencji, czynności inwen- } \\
\text { taryzacyjnych i prac spra- } \\
\text { wozdawczych }\end{array}$ & $\begin{array}{l}\text { słuchacz potrafi samo- } \\
\text { dzielnie i grupowo ana- } \\
\text { lizować i proponować roz- } \\
\text { wiązania organizacyjne } \\
\text { z zakresu rachunkowości } \\
\text { oraz funkcjonowania dzia- } \\
\text { łu rachunkowości; doce- } \\
\text { nia znaczenie kodeksu } \\
\text { etyki zawodowej }\end{array}$ \\
\hline $\begin{array}{l}\text { Rachunkowość } \\
\text { finansowa I }\end{array}$ & 20 & $\begin{array}{l}\text { słuchacz ma pogłębioną } \\
\text { wiedzę z zakresu szcze- } \\
\text { gółowych zagadnień wy- } \\
\text { ceny i ewidencji rzeczo- } \\
\text { wego majątku trwałego, } \\
\text { wartości niematerialnych } \\
\text { i prawnych, środków pie- } \\
\text { niężnych i rozrachunków }\end{array}$ & $\begin{array}{l}\text { słuchacz potrafi wyce- } \\
\text { niać i ewidencjonować } \\
\text { rzeczowy majątek trwały, } \\
\text { wartości niematerialne } \\
\text { i prawne, środki pieniężne } \\
\text { i rozrachunki; rozumie } \\
\text { przyczyny przyjęcia okre- } \\
\text { ślonych metod wyceny } \\
\text { do poszczególnych skład- } \\
\text { ników }\end{array}$ & $\begin{array}{l}\text { słuchacz posiada zdol- } \\
\text { ność do samodzielnego } \\
\text { lub zespołowego rozwią- } \\
\text { zywania zagadnień doty- } \\
\text { czących przedmiotu; ro- } \\
\text { zumie społeczne konse- } \\
\text { kwencje popelniania w nich } \\
\text { błędów księgowych }\end{array}$ \\
\hline $\begin{array}{l}\text { Podstawy } \\
\text { sprawozdaw- } \\
\text { czości } \\
\text { finansowej }\end{array}$ & 10 & $\begin{array}{l}\text { słuchacz zna istotę i ele- } \\
\text { menty sprawozdawczości } \\
\text { finansowej, definiuje i in- } \\
\text { terpretuje kategorie bilan- } \\
\text { sowe i wynikowe }\end{array}$ & $\begin{array}{l}\text { słuchacz potrafi zgroma- } \\
\text { dzić i pogrupować dane } \\
\text { niezbędne do sporządze- } \\
\text { nia bilansu i rachunku } \\
\text { zysków i strat; właściwie } \\
\text { odczytuje informacje za- } \\
\text { warte w tych sprawoz- } \\
\text { daniach }\end{array}$ & $\begin{array}{l}\text { słuchacz kształtuje ce- } \\
\text { chy niezbędne do wyko- } \\
\text { nywania zawodu, takie } \\
\text { jak: rzetelność, uczci- } \\
\text { wość, obowiązkowość }\end{array}$ \\
\hline $\begin{array}{l}\text { Rachunkowość } \\
\text { informatyczna }\end{array}$ & 20 & $\begin{array}{l}\text { słuchacz zna zasady ob- } \\
\text { sługi wybranego programu } \\
\text { do informatycznego prowa- } \\
\text { dzenia ksiąg rachunkowych }\end{array}$ & $\begin{array}{l}\text { słuchacz potrafi obsługi- } \\
\text { wać wszystkie opcje wy- } \\
\text { branego programu księ- } \\
\text { gowego i rozumie zasady } \\
\text { jego funkcjonowania }\end{array}$ & $\begin{array}{l}\text { słuchacz działa ze świa- } \\
\text { domością potrzeby usta- } \\
\text { wicznego kształcenia się } \\
\text { w zakresie zagadnień } \\
\text { związanych z wykorzys- } \\
\text { taniem programów księ- } \\
\text { gowych }\end{array}$ \\
\hline $\begin{array}{l}\text { Podstawy prawa } \\
\text { podatkowego }\end{array}$ & 10 & $\begin{array}{l}\text { słuchacz ma wiedzę z za- } \\
\text { kresu ordynacji podat- } \\
\text { kowej, prawa o podatkach } \\
\text { dochodowych i podatku } \\
\text { VAT }\end{array}$ & $\begin{array}{l}\text { słuchacz potrafi zasto- } \\
\text { sować praktycznie wiedzę } \\
\text { z zakresu ordynacji po- } \\
\text { datkowej, prawa o podat- } \\
\text { kach dochodowych i po- } \\
\text { datku VAT }\end{array}$ & $\begin{array}{l}\text { słuchacz jest przygoto- } \\
\text { wany do prawidłowego } \\
\text { rozstrzygania dylematów } \\
\text { z zakresu prawa podat- } \\
\text { kowego; przewiduje spo- } \\
\text { łeczne skutki swoich decyzji }\end{array}$ \\
\hline
\end{tabular}


Tabela 2. Treści programowe oraz zakładane efekty kształcenia na studiach podyplomowych „Rachunkowość” na Wydziale Ekonomicznym ZUT w Szczecinie (cd.)

\begin{tabular}{|c|c|c|c|c|}
\hline \multirow{2}{*}{$\begin{array}{l}\text { Nazwa } \\
\text { przedmiotu }\end{array}$} & \multirow{2}{*}{$\begin{array}{l}\text { Liczba } \\
\text { godzin }\end{array}$} & \multicolumn{3}{|c|}{ Zakładane efekty kształcenia } \\
\hline & & wiedza & umiejętności & $\begin{array}{c}\text { inne kompetencje } \\
\text { społeczne }\end{array}$ \\
\hline $\begin{array}{l}\text { Zobowiązania } \\
\text { ZUS }\end{array}$ & 9 & $\begin{array}{l}\text { słuchacz zna zagadnienia } \\
\text { dotyczące ustalania rozli- } \\
\text { czania i dokumentowania } \\
\text { zobowiązań ZUS }\end{array}$ & $\begin{array}{l}\text { słuchacz potrafi ustalić } \\
\text { i rozliczyć zobowiązanie } \\
\text { wobec ZUS oraz spo- } \\
\text { rządzić odpowiednią do- } \\
\text { kumentację w tym zakresie }\end{array}$ & $\begin{array}{l}\text { słuchacz zna skutki za- } \\
\text { chowań nieetycznych wy- } \\
\text { nikających z nieprawid- } \\
\text { łowości w rozliczeniach } \\
\text { z ZUS }\end{array}$ \\
\hline $\begin{array}{l}\text { Ewidencje } \\
\text { podatkowe }\end{array}$ & 10 & $\begin{array}{l}\text { słuchacz potrafi objaśnić } \\
\text { zasady prowadzenia ewi- } \\
\text { dencji podatkowych dla } \\
\text { różnych form opodatko- } \\
\text { wania działalności gospo- } \\
\text { darczej oraz zasady nali- } \\
\text { czania i rozliczania zobo- } \\
\text { wiązań podatkowych }\end{array}$ & $\begin{array}{l}\text { słuchacz potrafi określić } \\
\text { warunki wyboru poszcze- } \\
\text { gólnych form opodatko- } \\
\text { wania, przedstawić zakres } \\
\text { i metody prowadzenia za- } \\
\text { pisów w ewidencji / księ- } \\
\text { gach podatkowych i do- } \\
\text { konywać na ich podsta- } \\
\text { wie rozliczeń podatkowych }\end{array}$ & $\begin{array}{l}\text { słuchacz działa w spo- } \\
\text { sób przedsiębiorczy ze } \\
\text { świadomością potrzeby } \\
\text { kształcenia się ustawi- } \\
\text { cznego w zakresie treści } \\
\text { zajęć, a także występo- } \\
\text { wania zachowań nieetycz- } \\
\text { nych i konsekwencji błę- } \\
\text { dów oraz oszustw podat- } \\
\text { kowych }\end{array}$ \\
\hline Razem & 109 & & & \\
\hline \multicolumn{5}{|c|}{ II semestr } \\
\hline $\begin{array}{l}\text { Rachunkowość } \\
\text { finansowa II }\end{array}$ & 30 & $\begin{array}{l}\text { słuchacz ma pogłębioną } \\
\text { wiedzę z zakresu szcze- } \\
\text { gółowych zagadnień wy- } \\
\text { ceny i ewidencji zapasów, } \\
\text { instrumentów finansowych, } \\
\text { rezerw, rozliczeń między- } \\
\text { okresowych kosztów i przy- } \\
\text { chodów, kapitałów }\end{array}$ & $\begin{array}{l}\text { słuchacz potrafi wyceniać } \\
\text { i ewidencjonować zapa- } \\
\text { sy, instrumenty finanso- } \\
\text { we, rezerwy, rozliczenia } \\
\text { międzyokresowe kosz- } \\
\text { tów i przychodów, kapitały }\end{array}$ & $\begin{array}{l}\text { słuchacz posiada zdol- } \\
\text { ność do samodzielnego } \\
\text { lub zespołowego rozwią- } \\
\text { zywania zadań stano- } \\
\text { wiących przedmiot zajęć; } \\
\text { zna konsekwencje za- } \\
\text { chowań nieetycznych }\end{array}$ \\
\hline $\begin{array}{l}\text { Zaawansowana } \\
\text { sprawozdaw- } \\
\text { czość finansowa }\end{array}$ & 10 & $\begin{array}{l}\text { słuchacz zna zasady two- } \\
\text { rzenia rachunku przepły- } \\
\text { wów pieniężnych oraz } \\
\text { zestawienia zmian w ka- } \\
\text { pitale własnym }\end{array}$ & $\begin{array}{l}\text { słuchacz potrafi sporzą- } \\
\text { dzić rachunek przepływów } \\
\text { pieniężnych oraz zesta- } \\
\text { wienia zmian w kapitale } \\
\text { własnym }\end{array}$ & $\begin{array}{l}\text { słuchacz potrafi samo- } \\
\text { dzielnie i grupowo roz- } \\
\text { wiązywać zadania zwią- } \\
\text { zane z treścią przedmiotu }\end{array}$ \\
\hline $\begin{array}{l}\text { Podstawy } \\
\text { rachunku } \\
\text { kosztów }\end{array}$ & 20 & $\begin{array}{l}\text { słuchacz zna istotę i pod- } \\
\text { stawowe zagadnienia ra- } \\
\text { chunku kosztów oraz za- } \\
\text { sady jego funkcjonowania } \\
\text { według polskiego prawa } \\
\text { bilansowego }\end{array}$ & $\begin{array}{l}\text { słuchacz potrafi odróżnić } \\
\text { koszty od pojęć blisko- } \\
\text { znaczych; posiada umie- } \\
\text { jętność klasyfikacji kosz- } \\
\text { tów, zasad ich pomiaru, } \\
\text { ewidencji i ujęcia w ra- } \\
\text { chunku zysków i strat }\end{array}$ & $\begin{array}{l}\text { słuchacz potrafi samodzie- } \\
\text { Inie rozwiązywać proble- } \\
\text { my związane z realiza- } \\
\text { cją poszczególnych eta- } \\
\text { pów tradycyjnego rachun- } \\
\text { ku kosztów }\end{array}$ \\
\hline $\begin{array}{l}\text { Analiza } \\
\text { finansowa }\end{array}$ & 15 & $\begin{array}{l}\text { słuchacz zna zasady inter- } \\
\text { pretacji pozycji sprawoz- } \\
\text { dawczych, podstawowe } \\
\text { wskaźniki oceny sytuacji } \\
\text { majątkowej i finansowej } \\
\text { jednostki }\end{array}$ & $\begin{array}{l}\text { słuchacz potrafi interpre- } \\
\text { tować sprawozdanie fina- } \\
\text { nsowe za pomocą odpo- } \\
\text { wiednich wskaźników, do- } \\
\text { konuje ich właściwego do- } \\
\text { boru }\end{array}$ & $\begin{array}{l}\text { słuchacz posiada zdol- } \\
\text { ność do samodzielnego } \\
\text { lub zespołowego rozwią- } \\
\text { zywania zadań stano- } \\
\text { wiących przedmiot zajęć }\end{array}$ \\
\hline Razem & 65 & & & \\
\hline
\end{tabular}

Źródło: Sylabusy przedmiotów na studiach podyplomowych „Rachunkowość” prowadzonych na Wydziale Ekonomicznym ZUT w Szczecinie. 


\section{METODA}

Procesy ewaluacyjne mogą przebiegać przy wykorzystaniu różnych metod i technik badawczych. Zazwyczaj osoby prowadzące ewaluację programów studiów korzystają z następujących technik zbierania informacji, takich jak: ankieta, wywiad, obserwacje oraz analizy dokumentów. Każda z tych technik wskazuje różne aspekty tego samego przedsięwzięcia. W badaniu ewaluacyjnym programu studiów podyplomowych „Rachunkowość” na Wydziale Ekonomicznym ZUT w Szczecinie wybrano technikę ankietową. Opracowany formularz ankiety składał się z 3 części. W pierwszej części ankietowani odpowiadali na pytania dotyczące doboru poszczególnych przedmiotów na studiach podyplomowych z zakresu rachunkowości, a w drugiej części oceniali organizację formalną tych studiów, natomiast w części trzeciej - sposób prowadzenia zajęć przez nauczycieli. Zakres tematyczny ankiety został przedstawiony w tab. 3 .

Tabela 3. Zakres tematyczny ankiety: Ocena studiów podyplomowych „Rachunkowość” na Wydziale Ekonomicznym ZUT w Szczecinie

\begin{tabular}{|c|c|c|}
\hline Lp. & $\begin{array}{l}\text { Obszary oceny } \\
\text { studiów } \\
\text { podyplomowych }\end{array}$ & Pytania i propozycje \\
\hline \multirow[b]{2}{*}{ I } & \multirow{2}{*}{$\begin{array}{l}\text { Ocena } \\
\text { programu } \\
\text { studiów }\end{array}$} & 1. Jak ocenia Pan(-i) dobór przedmiotów? (skala ocen: 1-3 pkt) \\
\hline & & $\begin{array}{l}\text { 2. Prosze przedstawić propozycje przedmiotów wraz z liczbą godzin dla danego } \\
\text { przedmiotu według własnego uznania, o ile ma Pan(-i) uwagi do programu studiów }\end{array}$ \\
\hline \multirow{8}{*}{ II } & \multirow{8}{*}{$\begin{array}{l}\text { Ocena } \\
\text { organizacji } \\
\text { studiów }\end{array}$} & 1. Czy wszystkie zajęcia odbywały się zgodne z programem? (tak / nie) \\
\hline & & 2. Jeżeli zajęcia się nie odbyły, proszę podać przyczynę (nazwa przedmiotu, przyczyna) \\
\hline & & 3. Jak ocenia Pan(-i) pracę sekretariatu? (skala ocen: 1-3 pkt) \\
\hline & & $\begin{array}{l}\text { 4. Czy odpowiada Panu(-i) harmonogram zajęć, które były prowadzone w semestrach } \\
\text { I i II? (tak / nie) }\end{array}$ \\
\hline & & $\begin{array}{l}\text { 5. Jeżeli nie odpowiada Panu(-i) harmonogram zajęć, proszę przedstawić propozycję } \\
\text { zmian }\end{array}$ \\
\hline & & $\begin{array}{l}\text { 6. Czy odpowiada Panu(-i) forma dokonywanych zaliczeń przedmiotów i egzaminów? } \\
\text { (tak / nie) }\end{array}$ \\
\hline & & $\begin{array}{l}\text { 7. Jeżeli nie odpowiada Panu(-i) forma dokonywanych zaliczeń, proszę przedstawić } \\
\text { propozycję zmian (przedmiot / proponowana forma zaliczeń i egzaminów) }\end{array}$ \\
\hline & & 8. Inne uwagi o stronie formalno-organizacyjnej \\
\hline III & $\begin{array}{l}\text { Ocena } \\
\text { prowadzonych } \\
\text { zajęć }\end{array}$ & $\begin{array}{l}\text { Czy sposób prowadzenia zajęć przez wykładowców poszczególnych przedmiotów } \\
\text { odpowiada Pani(-i)? (skala ocen: } 1-3 \text { pkt) }\end{array}$ \\
\hline
\end{tabular}

Źródło: ankieta opracowana przez członków rady programowej studiów podyplomowych „Rachunkowość” na Wydziale Ekonomicznym ZUT w Szczecinie na potrzeby ich ewaluacji.

Badania ankietowe były przeprowadzane po zakończeniu cyklu kształcenia w danej edycji studiów podyplomowych. Słuchacze wypełniali ankietę podczas ostatnich zajęć na tych studiach; miała ona charakter anonimowy.

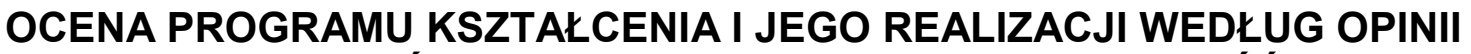 SŁUCHACZY STUDIÓW PODYPLOMOWYCH „RACHUNKOWOŚĆ” NA WYDZIALE EKONOMICZNYM ZACHODNIOPOMORSKIEGO UNIWERSYTETU TECHNOLOGICZNEGO W SZCZECINIE}

Ankiety zostały wypełnione przez słuchaczy 5 kolejnych edycji studiów podyplomowych „Rachunkowość” na Wydziale Ekonomicznym ZUT w latach 2011-2015; w okresie tym uzyskano 115 ankiet zwrotnych. 
Jak już wspomniano, słuchacze oceniali dobór przedmiotów umożliwiający zdobycie wiedzy i umiejętności z zakresu rachunkowości i prawa podatkowego przydatnych w pracy zawodowej. Wyniki tej części ankiety zostały przedstawione na ryc. 1.

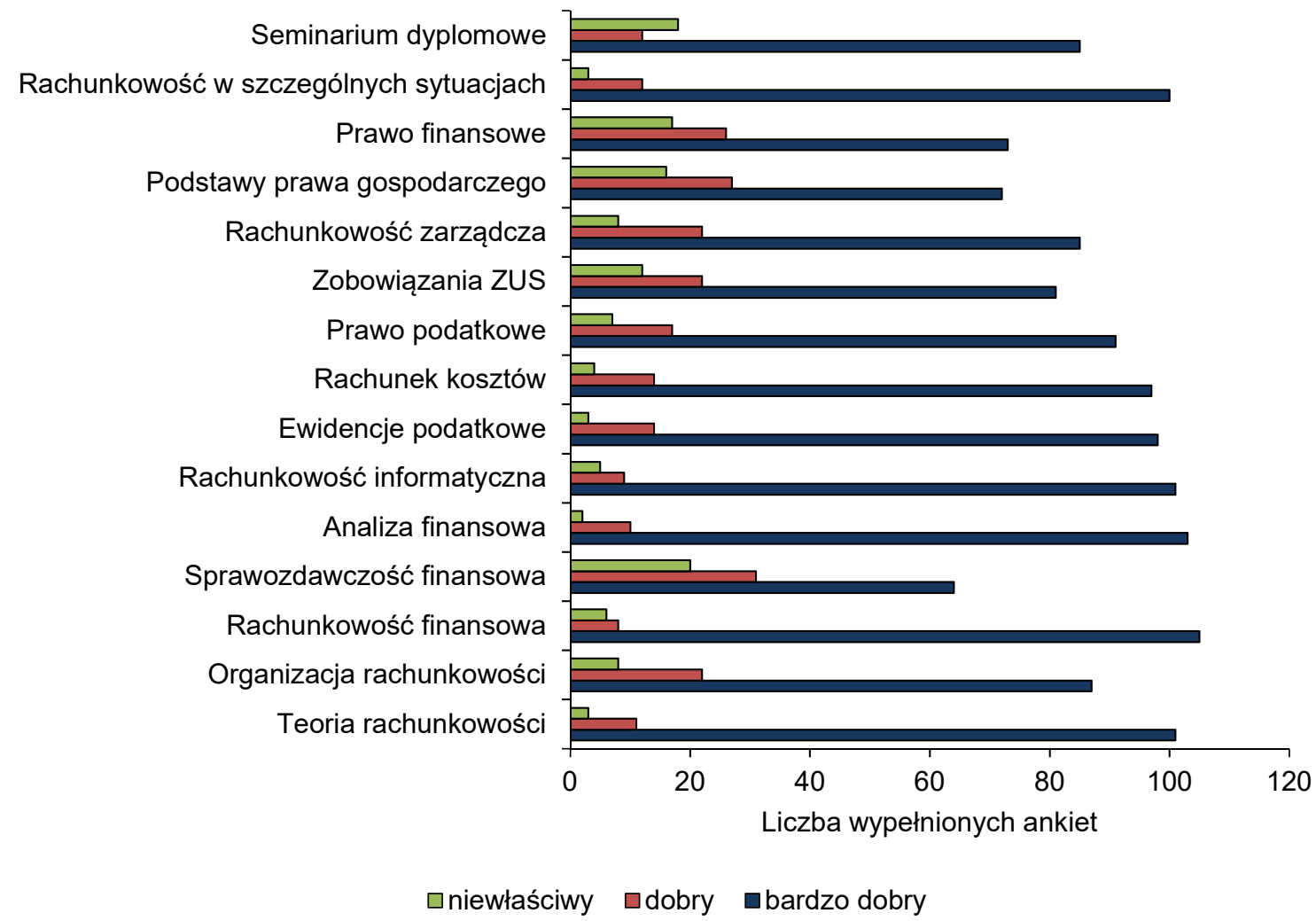

Ryc.1. Ocena doboru przedmiotów na studiach podyplomowych „Rachunkowość” ZUT w Szczecinie Źródło: opracowano na podstawie wyników badań ankietowych przeprowadzonych wśród słuchaczy studiów podyplomowych „Rachunkowość” ZUT w Szczecinie

Z informacji zawartych na ryc. 1 wynika, że słuchacze oceniali strukturę przedmiotów na studiach przed ich zmianą w 2016 r. Dla rady programowej tych studiów wyniki te stały się propozycjami zmian w programie studiów; propozycje te zostały zaaprobowane przez Radę Wydziału Ekonomicznego ZUT w Szczecinie. Wyeliminowano z programu te przedmioty, których dobór słuchacze ocenili najniżej ze względu na przydatność w wykonywaniu zawodów związanych z rachunkowością; dotyczyło to takich przedmiotów, jak: podstawy prawa gospodarczego, prawo finansowe, rachunkowość zarządcza. Przy czym pewne treści w nich zawarte znalazły się w treściach przedmiotów, które pozostały w programie studiów. Nie wyłączono z tego programu przedmiotu sprawozdawczość finansowa, który według opinii ankietowanych uzyskał najniższą ocenę ze względu na brak przydatności jego w wykonywaniu zawodów księgowych. Członkowie rady programowej uznali jednak ten przedmiot za niezbędny do zrozumienia całego procesu informacyjnego rachunkowości, sporządzanie sprawozdania finansowego jest bowiem efektem czynności organizacyjnych i ewidencyjnych w rachunkowości. Słuchacze najwyżej ocenili kolejno przydatność takich przedmiotów, jak: rachunkowość finansowa, analiza finansowa, teoria rachunkowości, ewidencje podatkowe, rachunkowość 
informatyczna, rachunkowość w szczególnych sytuacjach, rachunek kosztów, prawo podatkowe. Przedstawiona kolejność przydatności treści programowych ww. przedmiotów wydaje się uzasadniona ze względu na prace realizowane w ramach wykonywania zawodów księgowych.

Ankietowani mogli również przedstawić własne propozycje przedmiotów na studiach podyplomowych, wraz z liczbą godzin ich realizacji, w celu uzupełnienia programu. Słuchacze tylko w pojedynczych przypadkach proponowali rozszerzenie programu o systemy płacowo-kadrowe (1 osoba) czy rachunkowość w sektorze finansów publicznych (3 osoby). Pozostali ankietowani nie wskazywali konieczności włączenia nowych przedmiotów do programu studiów. Proponowali jednak zwiększenie liczby godzin z przedmiotów, które już się w nim znajdują; dotyczyło to takich przedmiotów, jak: prawo podatkowe (14 osób), ewidencje podatkowe (10 osób), rachunkowość informatyczna (10 osób), sprawozdawczość i rewizja finansowa (9 osób), rachunkowość finansowa (8 osób), rachunkowość w szczególnych sytuacjach (7 osób), analiza finansowa (3 osoby). Słuchacze studiów podyplomowych, podkreślając konieczność rozszerzenia treści programu o problematykę podatkową, proponowali rozbudowę tej tematyki głównie w przypadku podatku VAT. Wskazywali również na konieczność prowadzenia w większym zakresie zajęć laboratoryjnych przy komputerach.

Kolejny obszar oceny studiów podyplomowych dotyczył ich organizacji. Wszyscy ankietowani podkreślili, że zajęcia odbywały się zgodnie z programem. Bardzo wysoko ocenili również pracę osoby obsługującej sekretariat, w 100\% przyznając maksymalną liczbę punktów. $\mathrm{Na}$ pytanie dotyczące harmonogramu studiów pojedyncze osoby wskazały na konieczność bardziej równomiernego rozłożenia zajęć w poszczególnych miesiącach (2 osoby) oraz przeniesienia zajęć z piątku na niedzielę (1 osoba). Najwięcej zastrzeżeń dotyczyło przestrzegania w planie zajęć, w ramach semestru, kolejności poszczególnych przedmiotów ze względu na następstwo ich treści. Uwagi tego typu pojawiły się w wynikach badań ankietowych jednej tylko edycji, gdy zajęcia ze sprawozdawczości wyprzedziły treści programowe znajdujące się w I części rachunkowości finansowej. Zmiana kolejności przedmiotów w pierwszym semestrze miała być eksperymentem dydaktycznym, w którym zdecydowano się na niestandardowe nauczanie rachunkowości. Rozpoczęto wówczas proces nauczania od przedstawienia informacji zawartych w rocznym sprawozdaniu finansowym jednostki, aby następnie wyjaśniać podczas zajęć z rachunkowości finansowej sposób wyceny i ujęcia w księgach rachunkowych zdarzeń, których efektem jest określona wartość w pozycji sprawozdawczej.

Podejście to nie uzyskało akceptacji wśród słuchaczy studiów, w związku z czym w kolejnej edycji z niego zrezygnowano. Konsekwencją tego eksperymentu są jednak niższe oceny przydatności treści programowych sprawozdawczości finansowej w wykonywaniu zawodów księgowych. Wszystkim ankietowanym odpowiada również forma dokonywanych zaliczeń i egzaminów w trakcie semestrów. Niemniej (12 osób) ankietowanych wystąpiło z propozycją zrezygnowania z pisania i obrony pracy dyplomowej jako jednej z form oceny uzyskania kwalifikacji podyplomowych na tych studiach. Wskazywali na dużą pracochłonność tej formy potwierdzenia kwalifikacji; proponowali w zamian wprowadzenie egzaminu całościowego na koniec studiów.

W innych uwagach formalno-organizacyjnych w nielicznych przypadkach odnoszono się do formy przekazywania wiedzy. Zdania były w tym wypadku sprzeczne, np.: „słabo odbieram zajęcia prowadzone przy rzutniku” oraz „zamiast tablicy lepszym rozwiązaniem jest zastosowanie sprzętu audiowizualnego". Wskazywano również na zbyt dużą liczbę zaliczeń w trakcie jednego zjazdu (2 osoby). 
Kolejnym przedmiotem oceny była forma prowadzenia zajęć przez wykładowców. Ankietowani mieli do wyboru skalę ocen od 1 do 3 pkt. Przy czym cyfra 3 oznaczała bardzo dobre prowadzenie zajęć przez wykładowcę, cyfra 1 - niewłaściwe. Wyniki odpowiedzi na to pytanie przedstawia ryc. 2.

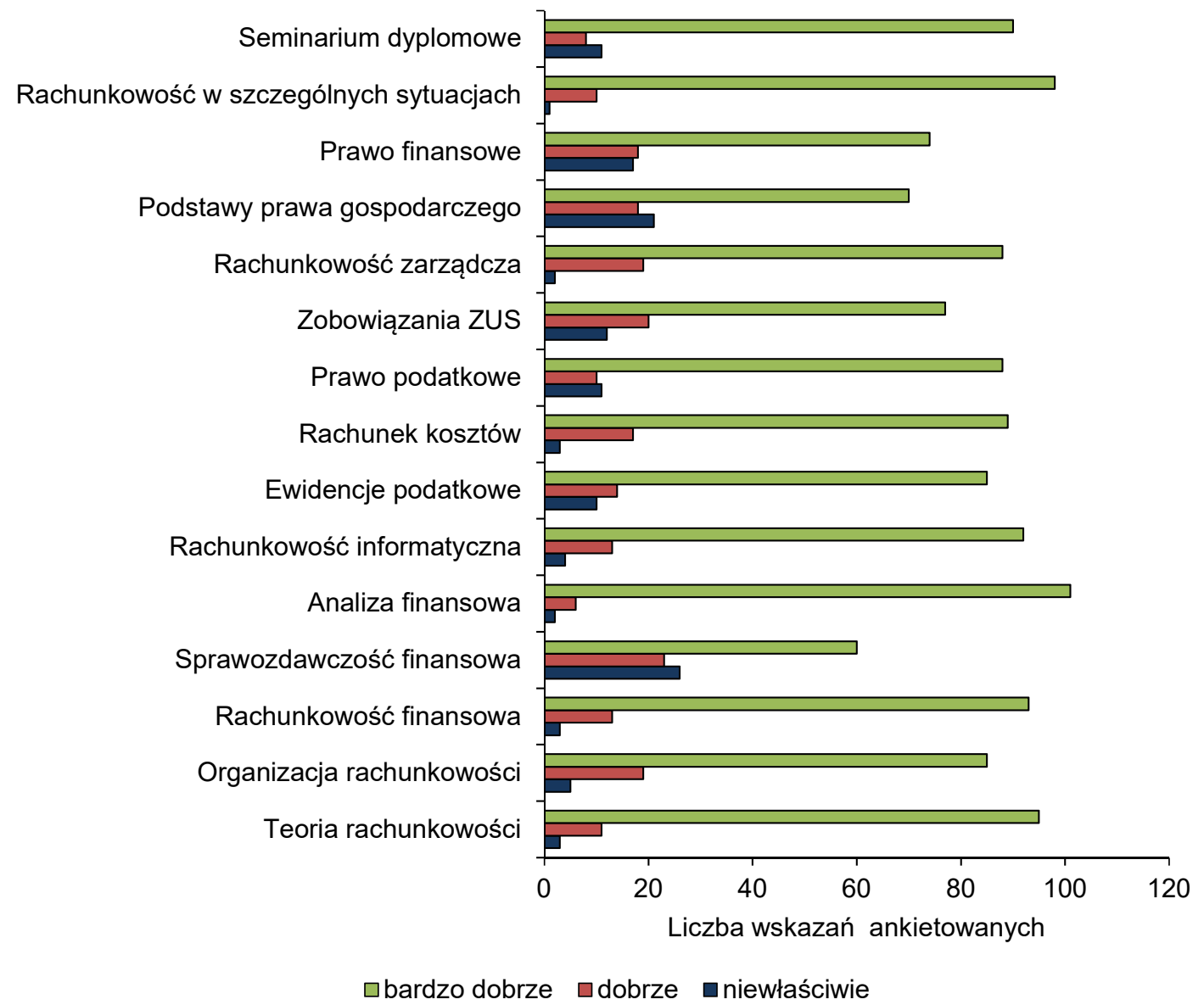

Ryc. 2. Ocena sposobu prowadzenia zajęć przez wykładowców

Źródło: opracowano na podstawie wyników badań ankietowych przeprowadzonych wśród słuchaczy studiów podyplomowych „Rachunkowość” ZUT w Szczecinie

Na postawie ryc. 2 można stwierdzić, że słuchaczom najbardziej odpowiada sposób prowadzenia zajęć z zakresu analizy finansowej, rachunkowości finansowej, rachunku kosztów, teorii rachunkowości, rachunkowości w szczególnych sytuacjach, rachunkowości zarządczej, rachunkowości informatycznej, prawa podatkowego, organizacji rachunkowości i ewidencji podatkowych. Najniższą ocenę uzyskała forma prowadzenia zajęć z zakresu sprawozdawczości finansowej, podstaw prawa gospodarczego i prawa finansowego. W większości niskie oceny za prowadzenie tych zajęć wystawili słuchacze z grupy, w której zmieniono tradycyjną kolejność przedmiotów w semestrze. Wpłynęło to na niezrozumienie przez słuchaczy treści programowych tego przedmiotu, co mogło mieć wpływ na późniejszą ocenę formy prowadzenia zajęć. Niższe oceny pozostałych wykładowców mogły wynikać z uznania przez słuchaczy nieprzydatności treści określonych przedmiotów do sprawnego wykonywania 
zawodów księgowych. Należy przy tym podkreślić, że mimo najniższych ocen uzyskanych przez tych wykładowców, w stosunku do innych nauczycieli prowadzących zajęcia na studiach, uzyskali oni od więcej niż połowy słuchaczy oceny bardzo dobre.

\section{PODSUMOWANIE}

Wyniki badań ankietowych wykazały, że przez kolejnych 5 edycji studiów podyplomowych słuchacze nie mieli większych zastrzeżeń do programu, organizacji i sposobu prowadzenia zajęć. Nieliczne mankamenty, które wskazywali w ankietach, dotyczyły doboru przedmiotów. Proponowali wycofanie przedmiotów prawnych, takich jak: prawo gospodarczego czy finansowe, aby w zamian rozszerzyć problematykę prawa podatkowego, ewidencji podatkowych czy rachunkowości finansowej i sprawozdawczości z użyciem komputera. Mając na uwadze te propozycje, zmieniono program studiów, eliminując z niego przedmioty, których treści według opinii słuchaczy mogą być mniej przydatne w wykonywaniu zawodów księgowych. Należy również zauważyć, że ankietowani podkreślali sprawną organizację studiów i bardzo dobre przygotowanie merytoryczne wykładowców.

\section{PIŚMIENNICTWO}

Definicje ewaluacji, http://www.pcdzn.edu.pl/publikacje/Granty/ewaluacja.pdf, dostęp: 20.11.2016.

Ewaluacja w pracy, http://erasmusplus.org.pl/wp cotent/uploads/2014/02/pajp_iv_ewaluacja_w_pracy.pdf, dostęp: 17.11.2016.

Guilbert J.J. 1990. Guide pedagogique pour les personnels de santa. Geneva, Organisation Mondiale de la Santa, 145.

March J.G., Simon A.H. 1964. Teoria organizacji. Warszawa, PWN, 145.

Mizikaci F. 2006. A systems approach to program evaluation model for quality in higher education. Quality Ass. Educ. 14(1), 37-53.

Nadolna B. 2013. Studia podyplomowe z zakresu rachunkowości i zasady ich akredytacji na potrzeby certyfikacji zawodu księgowego. Folia Pomer. Univ. Technol. Stetin., Oeconomica 303(72), 117-136.

Rozporządzenie Ministra Nauki i Szkolnictwa Wyższego z dnia 26 września 2016 r. w sprawie warunków prowadzenia studiów. DzU z 2016 r., poz.1596.

Słownik języka polskiego. 1988. Warszawa, PWN, 562.

Stachowiak-Kudła M. 2016. Ewaluacja jako instrument zapewnienia jakości kształcenia w szkolnictwie wyższym, w: Refleksyjnie o współczesnym zarządzaniu. Red. B. Kożuch, Ł. Sułkowski. Kraków, [b.w.], 216-226.

Ustawa z dnia 22 grudnia 2015 r. o Zintegrowanym Systemie Kwalifikacji. DzU z 2016 r., poz. 64, 1010.

Ustawa z dnia 27 lipca 2005 r. Prawo o szkolnictwie wyższym. DzU z 2016 r., poz.1842. 
